\title{
CHOSEN ASPECTS OF ANALYSIS OF ROAD TRAFFIC SAFETY IN POLAND BETWEEN 1995 AND 2008
}

\section{WYBRANE ASPEKTY ANALIZY BEZPIECZEŃSTWA RUCHU DROGOWEGO W POLSCE W LATACH 1995 - 2008}

\author{
Jerzy Kisilowski ${ }^{1}$, Jarosław Zalewski ${ }^{2}$ \\ (1) Warsaw University College of Technology and Business, Rector \\ 04-704 Warsaw, 11 Hafciarska St. \\ Warsaw University of Technology, Department of Transport, Prof. PhD. DSc \\ 00-662 Warsaw, 75 Koszykowa St. \\ (2) Warsaw University of Technology, \\ Faculty of Administration and Social Science, assistant \\ 00-662 Warsaw, 18/20 Noakowskiego St. \\ E-mails: rektorat@wste.pl,jz@wste.pl.
}

\begin{abstract}
In this paper certain occurrences are presented, resulting from statistical data concerning road traffic accidents in the period between 1995 and 2008. Some trends for the next years are also presented along with the consideration of certain indicators for Mazowieckie Voivodship. Analysis of the chosen data let us formulate the conclusions concerning the concrete aspects of road traffic safety both in Poland and Mazowsze. Attempt was made to evaluate the actual condition of road traffic safety as well as its upgrade.
\end{abstract}

Keywords: safety, accident, statistical data.

Streszczenie: $W$ niniejszym artykule zaprezentowane zostaty niektóre zjawiska wynikajace $z$ danych statystycznych dotyczacych wypadków drogowych $w$ latach 1995 - 2008 z uwzględnieniem trendów, jakie rysuja się na następne lata oraz z uwzględnieniem wybranych wskaźników dla województwa mazowieckiego. Analiza wybranych danych pozwolita na sformulowanie wniosków dotyczacych określonych aspektów bezpieczeństwa ruchu drogowego tak w Polsce, jak i na Mazowszu. Podjęto próbę oceny jego aktualnego stanu oraz zagadnień zwiq̨zanych z jego poprawa.

Słowa kluczowe: bezpieczeństwo, wypadek, dane statystyczne. 


\section{Introduction}

The problem of road traffic safety can be analysed in many ways. Their segmentation is necessary to find the reasons of road traffic incidents. Only acting on the causes of certain phenomena gives the possibility to eliminate their reasons. It is the point of view resulting from the observations and analysis with the use of randomness of phenomena. Such approach gives the opportunity to gain certain consequences, as well as making definite attempts to improve the condition of road traffic safety.

The authors do not claim the right to pass the final conclusions. We would like to create some doubts and encourage to such approach. Each of the presented phenomena can be the subject of separate analysis.

Statistical data was obtained from the road accident database of the Warsaw University College of Technology and Business, the Head Police Department, the Central Statistical Office and the European UN database.

\section{The main reasons of road accidents in the aspect of statistical data}

The analysis of the chosen data let us show the changes in results of road accidents between 1995 and 2008. Numbers of accident victims in this period are shown. The results of this analysis are compared with the available data concerning France. They will be the basis to formulate certain hypothesis.

Another set of results shows in what degree the human mistake was the cause of car accidents in the given period, compared to other causes. The accidents resulting from the previous deformations and disturbances in vehicle construction were not taken into account. Research within this scope are proceeded by the authors, however no one cares to support them financially.

The chosen data is presented in relation to 100000 road vehicles. Different comparable elements were determined for different time periods, which may cause discussion. We believe though, that the tendency is shown quite correctly. Some indicators are presented only for the chosen years from between 1995 and 2008, because there have been a lot of problems with data collection for each year.

Certain analysis was made in order to sketch the condition of road traffic safety in the given region, and what trends shape up for the forthcoming years in region Mazowsze.

In fig. 1 the proportional participation of different kinds of accidents in the period $1995-2008$ is shown, while in fig. 2 - in the period $2005-2008$. On 
this basis an assumption can be made, that both in the longer period and in a few last years the dominating type of accidents were side and rear crashes. These types are the most dangerous, often causing fatalities (especially in side crashes) and serious injuries, i.e. neck, chest and head.

Another important issue is the great amount of front crashes and incidents involving pedestrians, horse carriages, pulling tractors and cyclists, which could be avoided by modernizing road infrastructure.

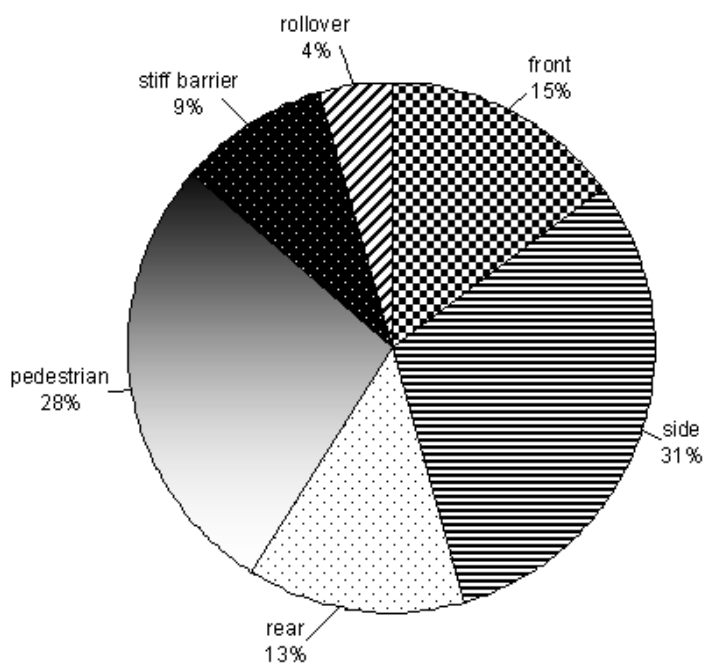

Fig. 1 Proportional participation of types of accidents in general number of accidents in Poland from 1995 to 2008.

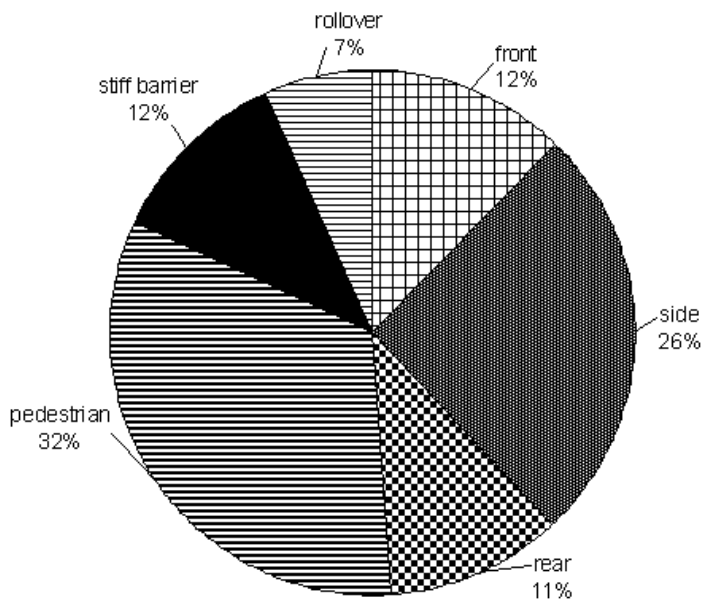

Fig. 2 Proportional participation of types of accidents in general number of accidents in Poland from 2005 to 2008. 


\subsection{The influence of road users on occurrence of accidents}

It is believed, that the fault of most accidents lies on human side. In fig. 3 the division into group of human faults is shown. The dominant group is, of course, the drivers group, having caused the most accidents every year. On this background only the pedestrians is a countable group. Despite the number of accidents caused by pedestrians fell between 2000 and 2004, the number of accidents caused by drivers remained on the same level, oscillating around 55000 per year. In the period of $2005-2008$ this number dropped rapidly. The number of accidents caused by pedestrians remained stable during the given period.

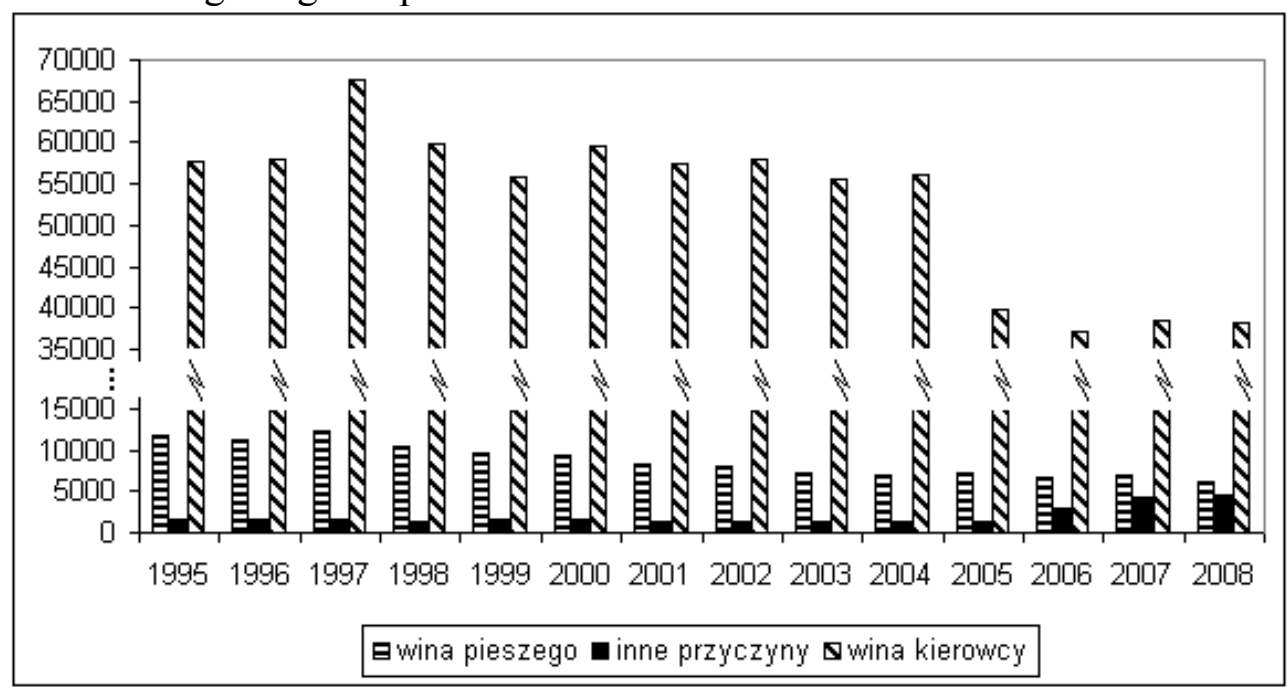

Fig. 3 Division of causes of road accidents from 1995 to 2008

Tab. 1. The number of accidents between 1995 and 2008 .

\begin{tabular}{|c|c|c|c|c|c|c|c|c|c|c|c|c|c|c|}
\hline YEA & 199 & 199 & 199 & 199 & 199 & 200 & 200 & 200 & 200 & 200 & 200 & 200 & 200 & 200 \\
\hline $\mathrm{R}$ & 5 & 6 & 7 & 8 & 9 & 0 & 1 & 2 & 3 & 4 & 5 & 6 & 7 & 8 \\
\hline 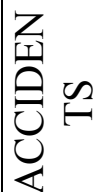 & $\begin{array}{l}\text { ठ } \\
\text { రి } \\
\text { ద }\end{array}$ & $\frac{\bar{a}}{\hat{a}}$ & $\begin{array}{l}0 \\
\infty \\
0 \\
0 \\
0\end{array}$ & $\begin{array}{l}\infty \\
\infty \\
\stackrel{n}{\sigma} \\
\end{array}$ & $\begin{array}{l}\stackrel{\circ}{n} \\
\tilde{n}\end{array}$ & $\begin{array}{l}\vec{m} \\
\stackrel{n}{n}\end{array}$ & $\begin{array}{l}\Omega \\
\frac{2}{n} \\
n\end{array}$ & $\begin{array}{l}n \\
n \\
n \\
n\end{array}$ & $\frac{\infty}{0}$ & $\begin{array}{l}\hat{b} \\
\frac{b}{n}\end{array}$ & 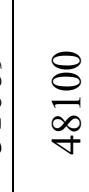 & \begin{tabular}{l}
0 \\
\multirow{\infty}{\infty}{} \\
\multirow{0}{0}{}
\end{tabular} & $\begin{array}{l}o \\
n \\
\tilde{a} \\
\sigma\end{array}$ & 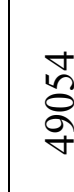 \\
\hline
\end{tabular}

The reasons for accidents and collisions have to be searched among the factors having influence on the smoothness of traffic. In fig. 4. the number of killed and injured in relation to 100000 accidents is shown. The second half of the given period looks more favorably. 
The significant decrease in the number of injured can be observed, from 600 in the period 1995 - 1999 to about 400 per 100000 vehicles in 2004 . The relative number of killed in road accidents stabilized after the period 1995 2000 at about 40 people per 100000 accidents. In the second period (20052008) further stabilisation of this indicator can be seen. It means that during 10 years it was possible to achieve a great decrease in the number of victims of accidents. The great role plays here the significant development of vehicle construction and safety technology. When joint with the development of road infrastructure, it can lead to further decrease in the number of killed at the expense of the number of injured. It is connected with separation of pedestrians and cyclists from car traffic, which is also mentioned later in this paper. In such case we can be expect the more frequent occurrence of rear and side crash accidents during lane change maneuver. The number of accidents involving front crash, pedestrians and cyclists, which often result in fatalities, should decrease.

The analysis of changes in the number of killed and injured is continued in fig. 5, where these changes are presented in relation to 1000 accidents in Poland over the period of 8 years. It is worth mentioning that the number of killed oscillates around 110, which allowed to observe certain stabilization for this indicator. In the period $2000-2008$ the number of injured per 1000 accidents oscillated around 1300. The situation is similar for Mazowsze, where the number of killed oscillated around 150, whereas the number of injured around 1200. It shows certain stabilisation in both areas.

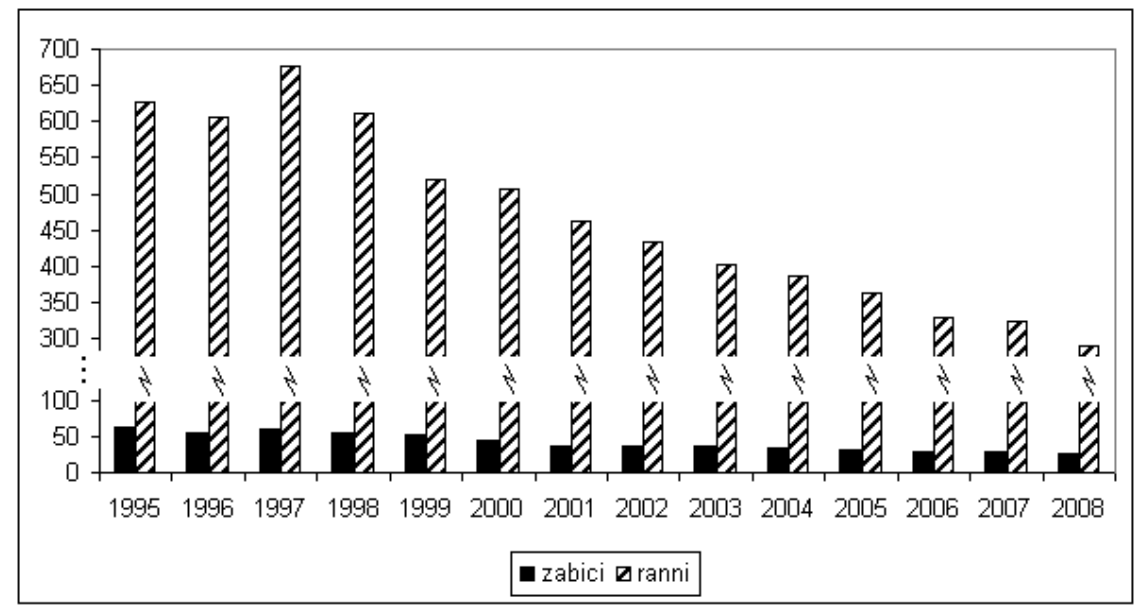

Fig. 4 The number of killed and injured from 1995 to 2008 in Poland in relation to 100000 registered vehicles. 


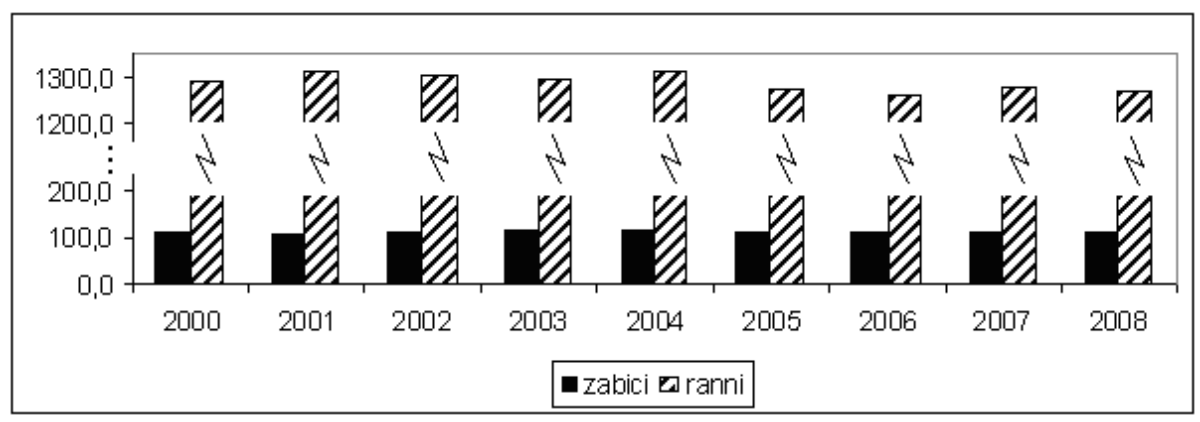

Fig. 5 The number of killed and injured per 1000 accidents in Poland from 2000 to 2008

The fact of high number of killed and injured in accidents in Mazowsze (fig. 6) is caused by certain important factors. First there is heavy traffic, especially in Warsaw and precincts, where logistic centers as well as magazines are located. Moreover the road infrastructure in Warsaw and around the city does not support the movement of such great number of vehicles. As a consequence the probability of dangerous situations increases. Another important problem is the concentration of vehicles in Mazowieckie Voivodship. In table 2 the number of vehicles per 1 $\mathrm{km}^{2}$ in the chosen voivodships and in Poland is shown for the period $2000-2008$.

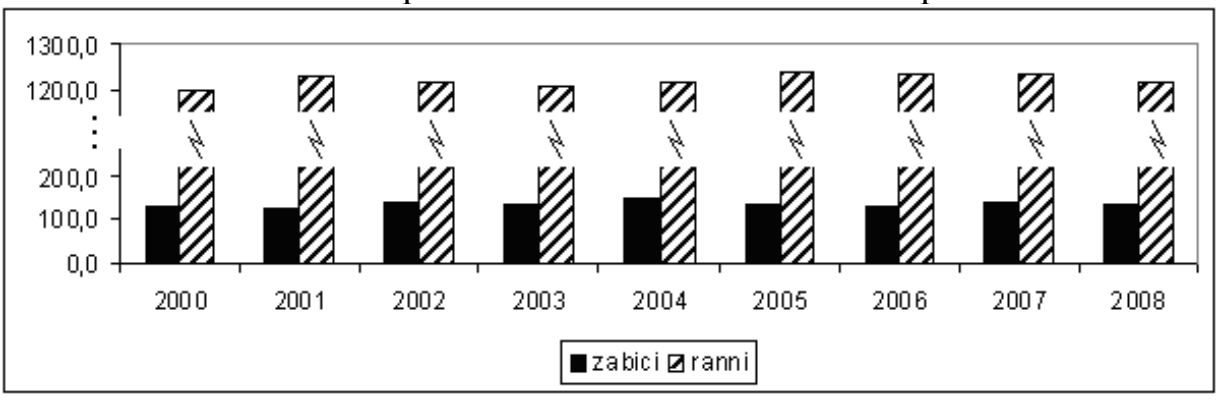

Fig. 6 The number of killed and injured per 1000 accidents in Mazowieckie Voivodship from 2000 to 2008.

Table 2. The number of vehicles per $1 \mathrm{~km}^{2}$ in the chosen voivodships and in Poland from 2002 to 2008.

\begin{tabular}{|c|c|c|c|c|}
\hline year & $\begin{array}{c}\text { Mazowieckie } \\
\text { Voivodship }\end{array}$ & Śląskie Voivodship & $\begin{array}{c}\text { Wielkopolskie } \\
\text { Voivodship }\end{array}$ & Poland \\
\hline 2002 & 67,51 & 140,96 & 56,46 & 49,65 \\
\hline 2003 & 70,15 & 139,69 & 57,69 & 50,85 \\
\hline 2004 & 72,98 & 145,48 & 60,27 & 53,41 \\
\hline 2005 & 73,98 & 152,80 & 58,08 & 53,78 \\
\hline 2006 & 79,45 & 162,53 & 61,94 & 57,68 \\
\hline 2007 & 86,26 & 174,10 & 66,77 & 62,27 \\
\hline 2008 & 94,47 & 189,12 & 73,54 & 68,24 \\
\hline
\end{tabular}


The concentration of vehicles in Mazowieckie is greater than in Poland. The difference is 20 vehicles per $1 \mathrm{~km}^{2}$ with the tendency of the further growth. As for the other voivodships, only Śląskie has greater concentration of vehicles, however the area of this region is smaller (tab. 3). For comparison, the area of Wielkopolskie is similar to Mazowieckie, but the concentration of vehicles is much smaller, especially in latter years of the given period.

Tab. 3. The number of vehicles and the area of voivodships from 2002 to 2008

\begin{tabular}{|c|c|c|c|c|c|c|c|c|}
\hline \multirow{2}{*}{ year } & \multicolumn{2}{|c|}{$\begin{array}{c}\text { Mazowieckie } \\
\text { Voivodship }\end{array}$} & \multicolumn{2}{c|}{$\begin{array}{c}\text { Śląskie } \\
\text { Voivodship }\end{array}$} & \multicolumn{2}{c|}{$\begin{array}{c}\text { Wielkopolskie } \\
\text { Voivodship }\end{array}$} & \multicolumn{2}{c|}{ Poland } \\
\cline { 2 - 10 } & $\begin{array}{c}\text { number } \\
\text { of } \\
\text { vehicles }\end{array}$ & $\begin{array}{c}\text { area } \\
{\left[\mathrm{km}^{2}\right]}\end{array}$ & $\begin{array}{c}\text { number } \\
\text { of } \\
\text { vehicles }\end{array}$ & $\begin{array}{c}\text { area } \\
{\left[\mathrm{km}^{2}\right]}\end{array}$ & $\begin{array}{c}\text { number } \\
\text { of } \\
\text { vehicles }\end{array}$ & $\begin{array}{c}\text { area } \\
{\left[\mathrm{km}^{2}\right]}\end{array}$ & $\begin{array}{c}\text { number } \\
\text { of } \\
\text { vehicles }\end{array}$ & $\begin{array}{c}\text { area } \\
{\left[\mathrm{km}^{2}\right]}\end{array}$ \\
\hline 2002 & 2402007 & 35579 & 1738118 & 12331 & 1683940 & 29826 & 15525733 & 312683 \\
\hline 2003 & 2495717 & 35579 & 1722515 & 12331 & 1720728 & 29826 & 15899195 & 312683 \\
\hline 2004 & 2595631 & 35567 & 1793948 & 12331 & 1797613 & 29826 & 16701072 & 312683 \\
\hline 2005 & 2630702 & 35559 & 1884136 & 12331 & 1732285 & 29826 & 16815923 & 312683 \\
\hline 2006 & 2824910 & 35557 & 2004617 & 12334 & 1847363 & 29827 & 18035047 & 312683 \\
\hline 2007 & 3067398 & 35558 & 2147343 & 12334 & 1991570 & 29827 & 19472000 & 312683 \\
\hline 2008 & 3359158 & 35558 & 2332561 & 12334 & 2193405 & 29827 & 21336913 & 312683 \\
\hline
\end{tabular}

\subsection{Comparison of the chosen indicators for Poland and France}

Table 4. People killed in accidents in Poland from 1998 to 2000 for the chosen types of road users.

\begin{tabular}{|c|c|c|c|c|c|c|c|}
\hline year & $\begin{array}{c}\text { No. of } \\
\text { accidents }\end{array}$ & pedestrians & $\begin{array}{c}\text { cyclists, } \\
\text { motorcycle } \\
\text { drivers }\end{array}$ & $\begin{array}{c}\text { horse } \\
\text { drawn } \\
\text { carriages }\end{array}$ & $\begin{array}{c}\text { front } \\
\text { crash }\end{array}$ & together & $\begin{array}{c}\text { people } \\
\text { killed in } \\
\text { total }\end{array}$ \\
\hline 1998 & 59649 & 2655 & 575 & 15 & 1274 & 4519 & 7080 \\
\hline 1999 & 53915 & 2446 & 643 & 11 & 1323 & 4423 & 6730 \\
\hline 2000 & 55464 & 2226 & 616 & 9 & 1286 & 4137 & 6294 \\
\hline
\end{tabular}

To fully asses the level of road safety in both countries it would be advisable to compare every type of accident. The range of comparisons is fragmentally presented in tab. 4. (difficulty in collecting the complete data, these aspects will be continued in further research). The result would be larger number of rear and front crash accidents in France, because there are a lot more speedways and highways than in Poland. On the other side, the historic city centers in France are often banned from the city traffic. 
Moreover the existence of ring roads can have a positive influence on the small number of side crash and pedestrian accidents. Although some indicators are close in value, the origins of this fact can be different.

In tab. 5 a set of data was presented for the period $2005-2007$. The number of killed in France was smaller than in Poland, although there were almost two times more accidents. Decreasing tendency for France can be observed here. Also in relative values the number of people killed in accidents is twice as high in France as in Poland, and the number of injured - about 100 people per 100000 vehicles less for France. The number of injured in Poland however, tends do keep falling in the given period.

Table 5. Victims of accidents for Poland and France from 2005 to 2007.

\begin{tabular}{|c|c|c|c|c|c|c|}
\hline \multirow{2}{*}{} & \multicolumn{7}{|c|}{ year } \\
\cline { 2 - 7 } & \multicolumn{2}{|c|}{2005} & \multicolumn{2}{c|}{2006} & \multicolumn{2}{c|}{2007} \\
\cline { 2 - 7 } & Poland & France & Poland & France & Poland & France \\
\hline accidents & 48100 & 84525 & 46876 & 80309 & 49536 & 81272 \\
\hline killed & 5444 & 5318 & 5243 & 4709 & 5583 & 4620 \\
\hline injured & 61191 & 79207 & 59123 & 75600 & 63224 & 76652 \\
\hline $\begin{array}{c}\text { no. of } \\
\text { registered } \\
\text { vehicles }\end{array}$ & 16815923 & 35757182 & 18035047 & 36072602 & 19472000 & 36524653 \\
\hline $\begin{array}{c}\text { accidents } \\
\text { per 100000 } \\
\text { RV }\end{array}$ & 286,03 & 236,38 & 259,91 & 222,63 & 254,39 & 222,51 \\
\hline $\begin{array}{c}\text { killed per } \\
100000 \\
\text { RV }\end{array}$ & 32,37 & 14,87 & 29,07 & 13,05 & 28,67 & 12,64 \\
\hline $\begin{array}{c}\text { injured per } \\
100000 \\
\text { RV }\end{array}$ & 363,88 & 221,51 & 327,82 & 209,57 & 324,69 & 209,86 \\
\hline
\end{tabular}

\section{Other causes of road accidents}

Human decisions play dominative role in road accidents and collisions. However, there are other factors that have their origins not related to making risky decisions directly before collision.

\subsection{Technical inefficiencies}

In fig. 7 technical inefficiencies as a cause of road accident were shown. Small increase of this indicator can be explained by the large number of 
vehicles of a doubtful technical condition, brought to Poland from abroad. This tendency can continue during the next years.

There is still lack of answer to what influence on road accidents have the vehicles, that had previously been damaged and repaired improperly. The parameters of a vehicle body is usually not checked on a special frame. There is also no clearly defined criteria of such examination.

Taking into account the consequences mentioned above the result can be the loss of stability. The reasons of this phenomena are mainly the deformation of a vehicle floor or the frame of a body as well as the change of moments of inertia and mass distribution in a vehicle. It would be advisable to consider introduction of measurements of mass - inertia parameters of a vehicle body after an accident and repair.

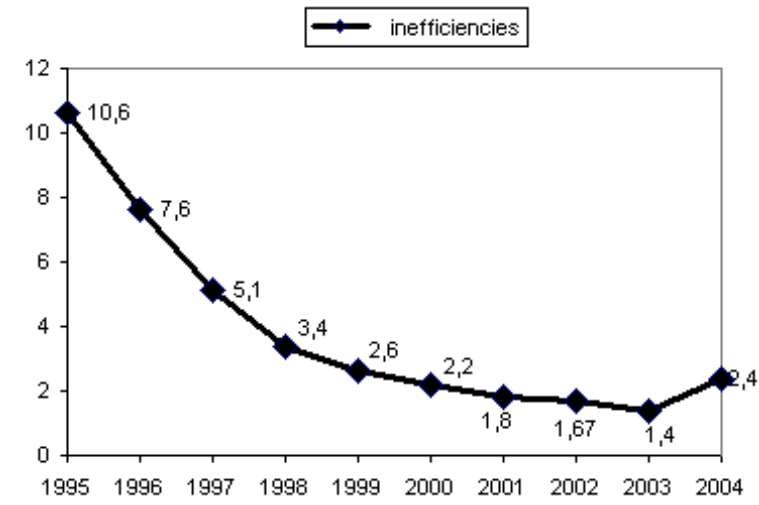

Fig. 7 Technical inefficiencies per 100000 vehicles in Poland

\subsection{Weather and road surface condidtions}

Analysis of weather and road conditions during road occurrence in the period 1999 - 2004 was made. Most accidents happened on dry road and in good weather conditions. (fig. 7, 8). It is connected to being more careful when the conditions are bad (fog, slippery road, etc.). Decrease of the number of accidents is connected to improvement of road infrastructure, which is easier than changing the habits of the drivers and make them apply to the requirements of the infrastructure. 


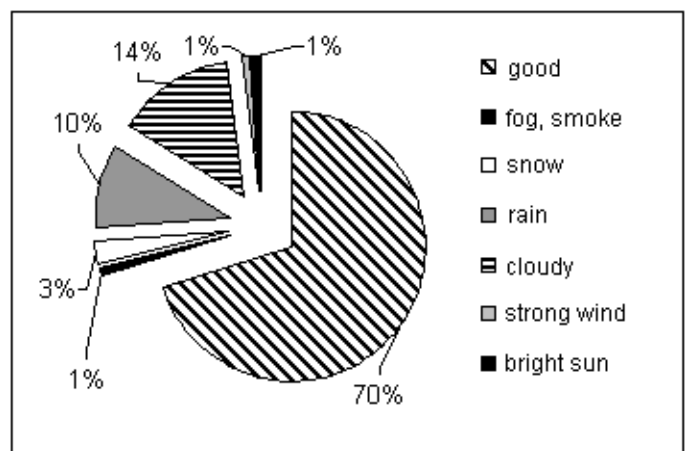

Fig. 8 Weather conditions during accidents from 1999 to 2004

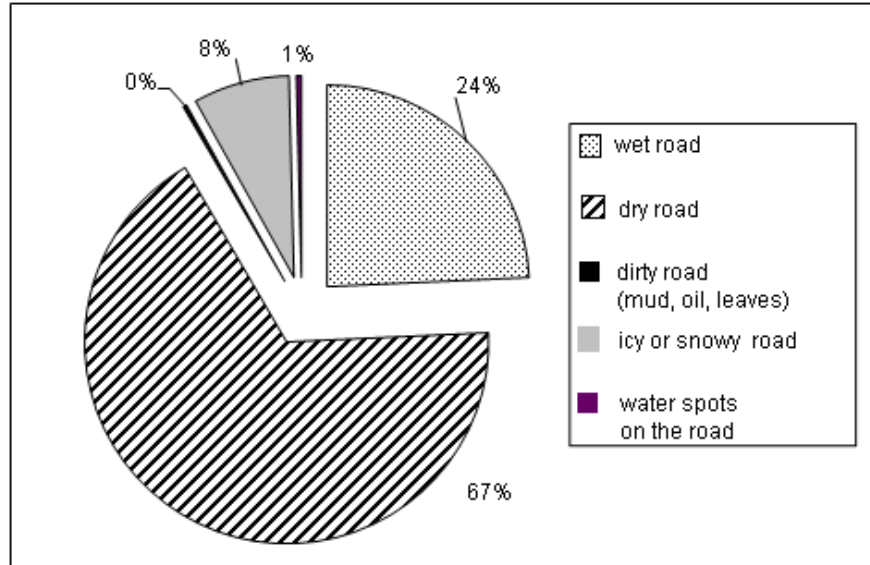

Fig.9 Proportional participation of accidents connected to the road condition from 1999 to 2004

\section{Accidents in urban and rural area}

In fig. 10 the number of accidents, killed and injured is shown in both urban and rural area from 2000 to 2004. From this data it is seen that most accidents happened in the urban area. Also there were more injured in towns and cities. I $t$ is undoubtedly the effect of accidents occurring during heavy traffic in the streets. It is a confirmation of the condition of road infrastructure.

In the given period the number of killed were greater for rural area, which can be explained by greater speed allowed on speedways as well as using the same infrastructure by different kinds of users, eg. pedestrians. 


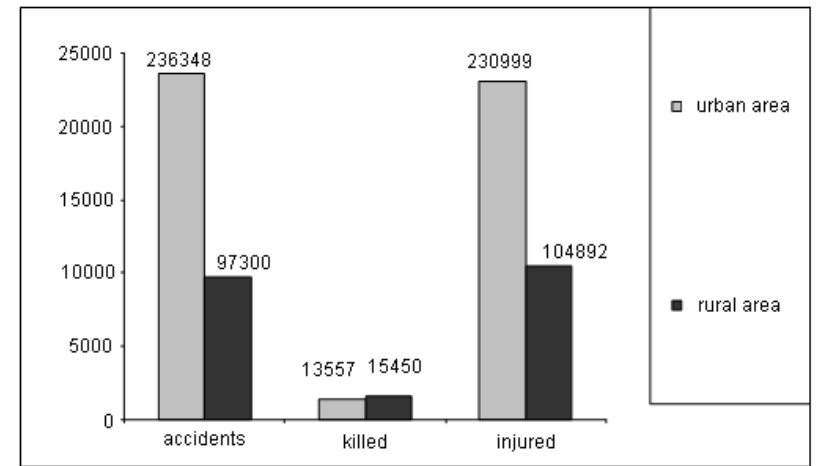

Fig. 10 Number of accidents, killed and injured in urban and rural area between 2000 and 2004

\section{Summary}

On the basis of relative values of data a claim can be made, that the number of accidents, killed and injured per 100000 vehicles for the given 10 years in Poland had visibly decreased. Moreover, in 2007 - 2008 certain stabilization in the number of killed occurred. Hence an assumption can be made that the road traffic safety has set on a concrete level.

Analysis concerning accidents and victims between France and Poland shows, that despite the decrease in numbers of killed and injured in accidents, it is still plenty to do in the matter of traffic safety, taking into account the fact, that there are over to times more cars and over two times less of killed in France.

\section{Conclusions}

The analysis show here are a complement of research over Road traffic safety. Thanks to their results some aspects not yet taken into account or not yet started can be noticed. It seems that so far the main directions of research has been: not keeping the allowed velocity and driving under the influence of alcohol. Those were considered the main reasons of road accidents.

From the presented results it is seen that both criteria mentioned above do not give the full picture of the condition of road traffic safety in Poland. The factors worth considering are: weather conditions at which accidents occur most frequently, vehicles that take part in accidents and road conditions along with different kinds of users on the same roads.

The most frequent In the given period were the side impact crashes and accidents involving pedestrians. However the incidents with pedestrians do 
not in general result in significant damage of the vehicle, the side impact crashes can in consequence lead to widespread damage of the vehicle body, and as a result, to the disturbance of its geometry. That influences the stability of a vehicle and is a consequence of a contact of two bodies with rough surfaces. Analysis of statistical data allowed to define the chosen relations specifying the level of road traffic safety in Poland and France. Those are not the results containing all of the problems of road traffic safety. Even the comparison of some indicators between France and Poland gives evidence of that. Only the claim can be made, that Road traffic safety has stabilized on a certain level (according to some indicators).

\section{References}

1. Konferencja naukowo techniczna: Problemy bezpieczeństwa w pojazdach samochodowych, Kielce 1998.

2. II konferencja naukowo-techniczna: Problemy bezpieczeństwa w pojazdach samochodowych, Kielce, 2000.

3. III konferencja naukowo-techniczna: Problemy bezpieczeństwa w pojazdach samochodowych, Kielce 2002.

4. Rajchel K.: Prawo drogowe, wypadki, Rzeszów, 1998, Politechnika Rzeszowska.

5. Szczuraszek T.: Bezpieczeństwo ruchu drogowego, WKŁ, Warszawa 2005.

6. Wicher, J.: Bezpieczeństwo samochodów i ruchu drogowego, WKŁ, Warszawa 2003.

7. Witan M.: Ocena powstawania szkód komunikacyjnych $w$ warunkach ruchu poza terenem zabudowanym, Praca Magisterska, Politechnika Warszawska, Warszawa 2006.

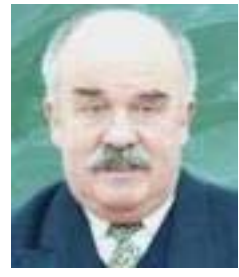

Jerzy Kisilowski, Prof. Full PhD. DSc.: Rector of Warsaw University College of Technology and Business. Works at the Faculty of Transport at Warsaw University of Technology. He specializes in measurement technology, electronics, informational systems, road traffic safety, mathematical modelling. He has over 300 publications in these areas.

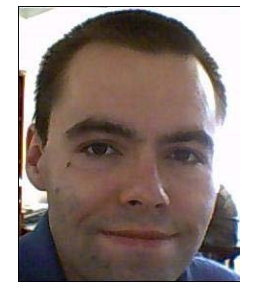

Jarosław Zalewski, MSc: Assistant at the Warsaw University College of Technology and Business. He attends PhD course at the Faculty of Transport (Warsaw University of Technology). He specializes in the problem of contact between road and tires, road traffic safety and statistical data collection. 